\title{
Media Convergence Welcomes Industry 4.0
}

\author{
http://dx.doi.org/10.25008/jkiski.v5i2.346
}

\author{
Ichsan Adil Prayogi ${ }^{1}$, Nuryah Asri Sjafirah ${ }^{2}$, Evie Ariadne Shinta Dewi ${ }^{3}$ \\ ${ }^{123}$ Faculty of Communication Sciences, Padjadjaran University \\ Jl. Raya Bandung - Sumedang KM 21, Jatinangor, West Java 45363 - Indonesia \\ *Corresponding author: ichsan18002@mail.unpad.ac.id
}

Submitted: February 09, 2020, Revised: November 19, 2020, Accepted: December 25, 2020

Accredited by Kemristekdikti No. 28/E/KPT/2019

\begin{abstract}
This article discusses how media convergence, as a new era of media in welcoming the industrial revolution, is not working properly. The purpose of this study is to explain how the media today still often create content with profit priority. By using Vincent Mosco's political economy theory and case studies on local media with national networks, the author tries to unravel how the media performs its functions. As a result, even though the media has developed more advanced with the era of digital media, the media is still often used for political interests or other interests through the titles or news content they make. To anticipate this, the general public should equip themselves with the capabilities of media literacy and digital literacy, so that they cannot choose a media that is suitable for consumption in the era of industrial revolution 4.0 where the media has developed into digital domain.
\end{abstract}

Keywords: Media convergence; digital media; vincent mosco; media literacy; digital literacy

\section{Introduction}

News is a journalistic product that is widely known to the public. To channel news to the audience, a channel called media is needed. From the past until now, users of messaging media have always evolved. In the past, we only knew print media as conventional media such as newspapers, magazines and tabloids. As technology develops, the media also develops. Until the term of media convergence became known.

Conventional media have evolved from newspapers to electronic media such as television, and to online media that is all digitized (new media). Media companies cannot avoid demand for media convergence (Prastya, 2017; Maryani, 2018; Putri \& Hamzah, 2018). The prospect of new media is in the possibility of participation, collaboarion and interaction between individuals (Arsenijević \& Andevski, 2015).

In this article the author tries to discuss the development of media companies towards media convergence. One of them is Radar Banten, a subsidiary of Jawa Pos Group, which has its own uniqueness. Among the local print media companies in Banten, only Radar Banten has its own printing machine. Whereas the others have to print their newspapers in Jakarta or Tangerang before selling them. This is the reason why the author chose Radar Banten to be discussed in this article. Moreover, Radar Banten is a local media company which has national readership and independent management.

The other consideration is the experience of the author who used to be a journalist based in Banten. The conversation with fellow senior journalists is one of the sources for this paper. This paper will further discuss how various media forms merge into one digital channel called media convergence.

The author will also try to link the writing to this paper with Vincent Mosco's media political economy theory, which centers on three media discussions about, commodification, spatialization and structuration (Mosco, 2009).

One of them will be related to the writing and example in this paper. At the end of this article the 
author will try to summarize how the current media that has entered digitalization began to homogenize the content and content of the news, and how the media's functions have shifted from social control, information sources and education in welcoming industry 4.0, but the media has become more pragmatic to reap profit.

\section{Theoretical Framework}

Geographically based mass media is divided into two, namely national newspapers published in Jakarta and widely circulating to all regions in Indonesia and local newspapers published and circulating within the scope of the province or district/city. Local newspapers are still considered important for the development of democracy, especially in the era of regional autonomy. The wheels of governance in regions, can run well, if the local media carry out the functions of control, knowledge, information, entertainment, and economic institutions. Local media revenue sources are mostly from local governments through advertisements product, advertorial and congratulatory advertisement.

Online journalism is the trend of today's media. Online journalism is the process of collecting, writing, editing and disseminating news online on the internet. Online journalism is a new generation of journalism after conventional journalism and broadcast journalism (Nurudin, 2011; Hutomo, 2020).

Online Journalism is journalism that utilizes the internet as a means of broadcasting news so that it can be accessed throughout the world. The theory that will be used in this article is Vincent Mosco's media political economy theory. This theory essentially centres on how the application of the political economy approach is used in mass media studies. This theory will be discussed further in the discussion of this article. To the relation with the object of research raised in this article.

\section{Material and Methodology}

The methodology in this article uses case studies. The case study is one approach to qualitative research which is presented by Creswell in his book titled qualitative research and research design. Case studies are qualitative approaches that examine a "case" in the realm of contemporary real-life (Cresswell, 2015). Researchers who use this approach can choose their research model based on objectives, namely single case studies (which focus on one particular issue or problem), intricate case studies (which focus on the case itself, because it is considered unique) and collective case studies (which utilize a variety of cases to illustrate one important thing from several perspectives).

In this article, the writer uses a direct interview to collect data from two respondents. The interview conducted by the writer was used to find out how the local newspaper Radar Banten with its national network carried out media convergence, and how should the public respond to it.

\section{Result and Discussion}

The findings in the field were obtained by the author by conducting interviews with Kang Hilal, the editor-in-chief of the "Zetizen" content and one-time general journalist for Radar Banten. He explained, speaking of content, Radar Banten is a media that has quite unique content. Radar Banten is the only print media in Banten that has content called "Zetizen", which comprises two to four pages to specifically discuss young people in Banten, with the aim of targeting teenage readers. Before being named "Zetizen", this teenagerspecific content was called "Xpresi". In 2015 the content changed its name to "Zetizen", with the frequency of publication being increased. Previously. "Xpresi" was only published once a week, Saturday or Sunday. But since it changed its name to "Zetizen", the frequency of publication is 3 times a week, namely Tuesday, Thursday and Saturday.

According to him, the content in Radar Banten has developed before entering the digitalization era. In early 2010 when "Xpresi" content was created, Radar Banten had indeed tried to share its content so that it could target all layers of readers in Banten. This content has developed thanks to facilities owned by Radar Banten. As the only local print media firm that has newspaper printing machine, Radar Banten has no difficulties developing or updating its content, to publish it to the public. From print to digital media, Radar Banten always tries to carry interesting contents. One of them is entertainment content regarding the issue of domestic life (usually husband's affair behind his wife) which they claim is based on a true story. By using the pseudonyms of the husband and wife and humorous caricatures, Radar Banten tried to make something different to the public. This content is considered unique and is not found in other local newspapers in Banten. The presence of "Xpresi" which changed into "Zetizen" with more frequency of publication is one of the examples.

The content areas of Radar Banten are more complete than those of other local print media. Why? This is because, according to Hilal, Radar Banten has more media crew members or field reporters than other media firms, so the coverage more varies. If in other media firm, according to 
him, one journalist can write two to four stories a day. However, in Radar Banten each journalist, particularly contributor only writes one story or three stories at the most a day, so the editor has a variety of stories to publish.

Hilal refused to divulge Radar Banten's news coverage which often made the headlines to support the Banten government or Radar Banten's relationship with the Banten government. However, another informant (who spoke on condition of anonymity) confirmed secret relations between Radar Banten and then Banten Governor Atut Chosiyah.

The informant who is a senior journalist and has close relations with Atut said as long as Atut was at the helm of Banten provincial government, his fellow reporters who specialized in covering the Banten provincial government's activities were often forced to write good content. Even some said that before the Corruption Eradication Commission (KPK) arrested Atut on corruption charges in 2013 the Radar Banten was known as the Banten government's "public relations" newspaper.

The news content like "public relations" have blurred the boundaries between commercial and editorial content. Analyzing Baudrillard's perspective, this news simulation is in the second stage of simulation, or evil appearance, in which people can no longer make a distinction between the real news and the advertising which simulate the news (Pasandaran, 2018).

After the arrest of Atut by the Commission in 2013, Radar Banten boldly and openly discussed the evils of the government of Atut and colleagues, starting from the number of corruption cases to the large number of Atut families who held strategic government positions in Banten. As stated by a senior journalist in Banten when the writer was a local journalist, it was true that Atut Chosiyah did not pay compensation to the Radar Banten for "sweet" reporting during her term of office.

This was the reason why Radar Banten finally became bold in criticizing the "spicy" government of Atut Chosiyah after she was arrested by the KPK at the end of 2013. If discussed theoretically, looking at the Radar Banten news coverage scheme while still supporting Atut, all advertisements usually used their power to force the editorial section to only raise the issue in favor of advertisers. On the other hand, the editorial section can use its power to preach an issue, even though the issue is assessed by the advertising section to corner clients who have been advertising.

The essence of domination is that the market becomes the main reference for media. This study includes a critical political economy that believes there is some group power over media reporting. Such is the case with cooperation between Radar Banten and Atut Chosiyah as Governor of Banten. This approach made by the author in the discussion at this article is because the author considers this approach gap relevant to the case in Radar Banten in 2013 and 2014. As for the online version of Radar Banten, they only rewrite the print media version on their website. By publishing enewspapers only, Radar Banten did not make too many breakthroughs in the digital version. According to Hilal, Radar Banten also often published news from Jawa Pos Network News (JPNN). This is natural since Radar Banten is a subsidiary of Jawa Pos Group owned by Dahlan Iskan.

In this example of field case, it is clear how Radar Banten prioritizes its publication for profit instead of social control, if associated with the theory of political economy of media, where the approach has the main character in the form of history because it seeks to understand social change and historical transformation in relation to economic, political, cultural and ideological moments of social development with dynamics rooted in socio-economic conflict. Here there is clear intervention from the Atut Chosiyah government in Radar Banten's news.

Consequently, Radar Banten's news has since 2012 tended to "praise" Atut and her Government. However, as compensation is not paid or anything other than "sweet" news, Radar Banten finally dares to raise the content or content of the news that is more critical of or tends to vilify Atut's government. This is, of course, based on the profit sought instead of social control of the general public, which is actually the function of the media. If discussed further to understand how the application of the political economy approach is used in mass media studies, there are three initial concepts that must be understood, namely: (1) Commodification, everything is commodified (considered an item merchandise), (2) Spatialization the process of overcoming obstacles of distance and time in social life; and (3) Structuration, uniform ideology structured.

Commodification is related to the process of transforming goods and services from the value of being a commodity-oriented to its exchange value on the market. In the process of transforming usevalue to exchange value, the mass media always involve media crew, audience of readers, markets and countries where each of them has an interest (Mosco, 2009). From the example above, it is clear that Radar Banten used its news as "a means" of making profit while at the same time putting aside 
the function of the media as social control. Good news which was critical of the Banten government was written during Atut's term of office not to carry out the function of the media as it should be, but rather based on an agreement reached beforehand.

Furthermore, there is Spatialization which is a way to overcome the obstacles of distance and time in social life. With the advancement of communication technology, distance and time are no longer obstacles in the practice of political economy. Spatialisation is related to the process of boundaries or is best said to be a transformation of boundaries of space and time in social life. It can also be said that spatialization is a process of media institutional extension through the form of the corporation and the size of the media business entity. The size of the media business entity can be horizontal or vertical.

Horizontal means that the form of the media business entity is conglomerate, monopoly forms. Vertical spatial process is an integration process between parent company and its subsidiary that operate in one business line to obtain synergy, especially to gain control of media production. In the example of this paper, Radar Banten is clearly the subsidiary of the Jawa Pos Group, the largest media network in Indonesia. The media company owned by Dahlan Iskan has a network of more than 100 branches under "Radar Groups" that are found almost in every city in Indonesia.

Finally, in this theory, structuration is discussed, namely structuring uniform ideology. The same media owner will have the same ideology. The contents of the media always reflect the interests of those who finance them (McQuail, 2011). Structuring is related to the relationship between agency ideas, social processes and social practices in structural analysis. Structuring is an interdependent interaction between agents and the social structure that surrounds them.

However, this does not mean that this perspective ignores the choices that have been determined by producers and consumers, but sees it in a larger structured structure. In Radar Banten taken as an example in this paper, they made a digital version of their media as a follow-up to media convergence. Most of content messages or news on online media are just rewritten from their print media, and the majority had a high level of social media usage pattern; thus, it can be said that social media has a great influence on the work pattern of journalists (Suraya, 2019).

In the digital version of the news Radar Banten also often displays news that is directly affiliated with Jawa Pos which has a digital network called "Jawa Pos Network News" (JPNN).
If that is the case, in other words, the news on Radar Banten's digital media is likely to be the same as that of other radar groups which are also affiliated directly to Jawa Pos. Keep in mind Jawa Pos with its network of radio newspaper groups, often mentions JPNN as the author of the news. The case examples in this article are only small examples of how media companies in Indonesia have begun to shift their function properly. In Indonesia alone, there are large media companies that are members of the media group that can make them survive. Among them are Mahaka Media Group with Erick Tohir as its owner, MNC Group with Hary Tanoesoedibjo as its owner, Jawa Pos Group with Dahlan Iskan as its owner, Berita Satu Media Holdings with James Riyadi as its owner, Media Group with Surya Paloh as its owner, Visi Media Asia with Aburizal Bakrie as its owner, and there are still few others. The ownership of such media groups should have an effect on the content or news they make. The oligarchic media owners will have to do with benefit if some of them are active in practical politics. The reseach conducted by Prasakti (Fahadi, 2019) talks about two media companies that made news content about presidential election 2014.

From this term, many media concentrate on individuals. Each individual who is a media literate has become a necessity for modern societies (Karaduman, 2015) as it is now. People should have media literacy ability to make it sure that they will be able to collect right and important infomation from media. Such skill does not need social skills such as having access to the internet (Akti \& Gürol, 2012), having more references source of news and choosing not to consume media of which owner has something to do with politics. All these can help have such skill, besides media literacy, digital literacy are also important due to media convergence and use of internet as their platform.

Digital literacy is absolutely necessary so that the new media truly benefits the audience, and not the other way around (Rianto, 2016). Digital literacy can be built from family, and the role of adults is really important in this case, In terms of children's digital literacy, adults play a very significant role in three main aspects: (1) As direct responsible of their digital literacy. (2) As enablers of behaviour models which promote a positive conviviality and cyber conviviality. (3) As adult referents which children can ask for help (Vélez et al., 2017).

The alignment of the media can be seen clearly when Indonesia enters a political year once every five years, where several media groups will show their partiality. In anticipation of this, ideally, 
the public should have media literacy or digital literacy so they can easily choose the media that is able to educate them and meet the information needs (Kelly Ku, Qiuyi Kong, 2019), especially in the industrial era 4.0 which is very sophisticated with increasingly rapid technological development. Media Group owned by Surya Paloh can be an example of media alignments when the political year arrives. Convergence of conventional media to digital media should be followed by harmonizing the function of the media itself so that audiences get their rights, and the media can function properly.

\section{Conclusions}

At this moment, Radar Banten can be said to be the number one local newspaper in Banten. In addition to having adequate supporting facilities, its content is also more diverse than that of other local print media in the province. In the past, those who once "served as" the Banten government public relations during Atut Chosiyah's term of office, where the Banten government's activities could be filled with a full page of colour, prove that the media is still often used for political interests. One of the examples is media group owned by Surya Paloh. With the digital version, the content will certainly be more difficult to control.

If media independence is maintained, the media can function as a public servant. If this happens, surely, the existing media content will also be able to provide information, educate and even entertain the general public, without any news that contains images or attacks on certain political groups. Media users must also have the ability to choose healthy media. Before entering media convergence, it is necessary to have digital literacy. Digital literacy is a screening or selection of content by the user or users on the platform -the existing digital platform. Whatever digital format is, such as online media and others, it does not always display content that is good for consumption by a wide audience. This digital literacy is very important because the content in the digital world needs to be filtered or filtered which is good and feasible to consume, considering the increasing number of new media outlets in the industrial revolution 4.0, the public also need to increase their ability to filter information on the media both conventional and digital.

\section{References}

Akti, S., \& Gürol, A. (2012). Determining the Relationship between Media Literacy and Social Skills. Procedia - Social and Behavioral Sciences, 64, 238-243. https://doi.org/10.1016/j.sbspro.2012.11.02

\section{8}

Arsenijević, J., \& Andevski, M. (2015). Media Convergence and Diversification - The Meeting of Old and New Media. Procedia Technology, 19, 1149-1155. https://doi.org/10.1016/j.protcy.2015.02.164

Cresswell, J. W. (2015). Qualitative Research and Design (3rd ed.). Putaka Pelajar.

Fahadi, P. R. (2019). Oligarchic Media Ownership and Polarized Television Coverage in Indonesia's 2014 Presidential Election. Jurnal Komunikasi Ikatan Sarjana Komunikasi Indonesia, 4(2), 77-86. https://doi.org/10.25008/jkiski.v4i2.328

Hutomo, M. S. (2020). Bertahan untuk Hidup: Konvergensi Pers Cetak dalam Industri Digital Media. CARAKA: Indonesian Journal of Communications, 1(1), 30-37.

Karaduman, S. (2015). The Role of Critical Media Literacy in Further Development of Consciousness of Citizenship. Procedia Social and Behavioral Sciences, 174, 30393043.

https://doi.org/10.1016/j.sbspro.2015.01.109 5

Kelly Ku, Qiuyi Kong, Y. S. (2019). The Role of Social Media News Consumption and News Media Literacy. Elsevier, 33(January). https://doi.org/100570

Maryani, E. (2018). Developing Social Solidarity through Digital Media. Jurnal Komunikasi Ikatan Sarjana Komunikasi Indonesia, 3(1), 12-17.

https://doi.org/10.25008/jkiski.v3i1.144

McQuail, D. (2011). Teori Komunikasi Massa Edisi 6. Salemba Humanika.

Mosco, V. (2009). The Political Economy of Communications (Seconds Ed). Sage.

Nurudin. (2011). Komunikasi Massa. Cespur.

Pasandaran, C. C. (2018). Political Advertising Camouflage As News. Jurnal Komunikasi Ikatan Sarjana Komunikasi Indonesia, 3(2). https://doi.org/10.25008/jkiski.v3i2.239

Prastya, N. M. (2017). Media Convergence and Human Resoucres Management in Sport Media Newsroom: Case Study in TopSkor Daily Newspaper. Jurnal Komunikasi Ikatan Sarjana Komunikasi Indonesia, 2(2), 57-64. https://doi.org/10.25008/jkiski.v2i2.70

Putri, C. E., \& Hamzah, R. E. (2018). Konvergensi Konten Majalah Popular dalam Industri Digital Media Cetak. Warta Ikatan Sarjana Komunikasi Indonesia, 1(02), 19-28.

Rianto, P. (2016). Media Baru, Visi Khalayak Aktif Dan Urgensi Literasi Media. Jurnal Komunikasi Ikatan Sarjana Komunikasi Indonesia, $\quad$ 1(2), 90. 
https://doi.org/10.25008/jkiski.v1i2.54

Suraya, S. (2019). Journalist Credibility Based on Digital Media Used. Jurnal Komunikasi: Ikatan Sarjana Komunikasi Indonesia, 4(1). https://doi.org/10.25008/jkiski.v4i1.261

Vélez, A. P., Olivencia, J. J. L., \& Zuazua, I. I. (2017). The Role of Adults in Children
Digital Literacy. Procedia - Social and Behavioral Sciences, 237(June 2016), 887892.

https://doi.org/10.1016/j.sbspro.2017.02.124 